\title{
The East African Long Rains in Observations and Models
}

\author{
Wenchang Yang, Richard Seager, And Mark A. CANe \\ Lamont-Doherty Earth Observatory, Columbia University, Palisades, New York \\ BRADFIELD LYON \\ International Research Institute for Climate and Society, \\ Lamont-Doherty Earth Observatory, Earth Institute at \\ Columbia University, Palisades, New York
}

(Manuscript received 26 July 2013, in final form 24 January 2014)

\begin{abstract}
Decadal variability of the East African precipitation during the season of March-May (long rains) is examined and the performance of a series of models in simulating the observed features is assessed. Observational results show that the drying trend of the long rains is associated with decadal natural variability associated with sea surface temperature (SST) variations over the Pacific Ocean. Empirical orthogonal function (EOF), linear regression, and composite analyses all show the spatial pattern of the associated SST field to be La Niña like. The SST-forced International Research Institute for Climate and Society (IRI) forecast models are able to capture the East African precipitation climatology, the decadal variability of the long rains, and the associated SST anomaly pattern but are not consistent with observations from the 1970s. The multimodel mean of the SST-forced models from the Coupled Model Intercomparison Project phase 5 (CMIP5) Atmospheric Model Intercomparison Project (AMIP) experiment captures the climatology and the drying trend in recent decades. The fully coupled models from the CMIP5 historical experiment, however, have systematic errors in simulating the East African precipitation climatology by underestimating the long rains while overestimating the short rains. The multimodel mean of the historical simulations of the long rains anomalies, which is the best estimate of the radiatively forced change, shows a weak wetting trend associated with anthropogenic forcing. The SST anomaly pattern associated with the long rains has large discrepancies with the observations. The results herein suggest caution in projections of East African precipitation from CMIP5 or the relationship between the East African precipitation and the SST spatial pattern found in paleoclimate studies with coupled climate models.
\end{abstract}

\section{Introduction}

East Africa was struck by a severe drought in 2010-11, the worst drought to occur in the region in the last 60 years, placing millions of people into a humanitarian crisis in this politically and socioeconomically vulnerable region (FEWS NET 2011; Lyon and DeWitt 2012). The drought is characterized by failure of two consecutive rainy seasons: the short rains, that is, the OctoberDecember (OND) rainy season; and the long rains, the March-May (MAM) rainy season (Camberlin and Philippon 2002). While the short rains failure was

Corresponding author address: Wenchang Yang, LamontDoherty Earth Observatory, Columbia University, 61 Route 9W, Palisades, NY 10964.

E-mail: wyang@ldeo.columbia.edu expected in the La Niña year of 2010 given the robust relationship with El Niño-Southern Oscillation (ENSO) (Ogallo 1988; Mason and Goddard 2001), there was difficulty in explaining the long rains failure since no robust forcing of the precipitation in this season, either oceanic or atmospheric, had been identified in past studies (Camberlin and Philippon 2002).

Lyon and DeWitt (2012) considered the belownormal long rains in 2011 against a longer time scale background. In contrast to Williams and Funk (2011), who suggested that the long rains have been in a multidecadal decline, Lyon and DeWitt (2012) proposed a different explanation. Williams and Funk (2011) associated the drying trend with an anthropogenic-forced relatively rapid warming of Indian Ocean sea surface temperatures (SSTs), which they contend extends the warm pool and Walker circulation westward, resulting 
in a subsidence anomaly and drying over East Africa. On the contrary, Lyon and DeWitt (2012) linked the decline in the East African long rains with a shift to warmer SSTs over the western tropical Pacific and cooler SSTs over the central and eastern tropical Pacific. Most recently, Lyon et al. (2014) have shown that the shift is part of natural multidecadal variability in the Pacific.

Paleoclimate studies have shown that East Africa has undergone dramatic hydroclimate variability on multidecadal or longer time scales (Verschuren et al. 2000; Russell and Johnson 2007) although the temporal resolution in paleoclimate records is not able to distinguish long rains from short rains. By using a Monte Carlo empirical orthogonal function (MCEOF) approach (Anchukaitis and Tierney 2013) to synthesize different hydroclimatic proxy records, Tierney et al. (2013) not only revealed many features of East African hydroclimate found in previous paleoclimate studies but also identified the spatial patterns of the features and associated uncertainties. In addition, Tierney et al. (2013) concluded on the basis of millennium-long control simulations from different atmosphere-ocean general circulation models (AOGCMs) and proxy records of ocean variability that the hydroclimate variability of East Africa on multidecadal time scales is controlled by the Indian Ocean. However, this conclusion depends in part on the capability of these models to simulate aspects of the current climate of East Africa (e.g., climatology and relationship with SSTs), which needs further validation.

A highly relevant issue is how the East African long rains will respond to the warming climate forced by anthropogenic emissions of greenhouse gases (GHGs). Climate model simulations assessed in the Intergovernmental Panel on Climate Change (IPCC) Fourth Assessment Report (AR4) or the more recent Coupled Model Intercomparison Project phase 5 (CMIP5; Taylor et al. 2012) suggest an expansion of the Hadley circulation ( $\mathrm{Lu}$ et al. 2007), enhancement of the precipitationminus-evaporation $(P-E)$ pattern (i.e., the wet area gets wetter and the dry area gets drier) (Held and Soden 2006; Seager et al. 2010), weakening of the Walker circulation (Vecchi and Soden 2007), and regional drying trends (Seager et al. 2007; Hoerling et al. 2011; Kelley et al. 2012). Of these changes, the $P-E$ pattern enhancement implies that the East African long rains, which are part of the intertropical convergence zone (ITCZ), will increase. In addition, weakening of the Walker circulation also suggests a wetting trend over East Africa, if the relationship between the East African long rains and the SSTs in Lyon and DeWitt (2012) and Lyon et al. (2014) is correct. However, observational studies have shown that the Walker circulation seemed to be strengthening over the twentieth century (Cane et al. 1997; Chen et al. 2002; Compo and Sardeshmukh 2010; L'Heureux et al. 2013). Further, the multimodel mean of the CMIP5 medium mitigation scenario [representative concentration pathway 4.5 (RCP4.5)] projections shows a wetting trend over East Africa (Fig. 1a) during the long rains season over the first half of the twenty-first century while high-resolution regional climate models forced with ensemble-mean GCM output on the boundaries lead to drier twenty-first-century long rains (Vizy and Cook 2012; Cook and Vizy 2013), which is probably consistent with the observed drying trend over the past three decades (Figs. 1b and 2a). These differences could be because of model error representing the forced change or because the observed record is dominated by natural variability. Determining whether the future in East Africa will be drier or wetter requires a careful examination of the ability of models to simulate realistic natural variability and forced changes.

In this paper, we will investigate the decadal variability of the East African long rains and its relationship with SSTs in observations and compare them with a series of model simulations, including the International Research Institute for Climate and Society (IRI) forecast models, SST-forced models from the CMIP5 Atmospheric Model Intercomparison Project (AMIP) experiments, and the CMIP5 historical simulations (coupled models). The key questions include the following: What is the character of decadal variability of the East African long rains in the observations over the past century? What is its relationship with the observed SSTs? Do the simulations from the SST-forced models and the fully coupled models capture these features? What does that imply for the model projections of the East African long rains precipitation in the near future? The paper is organized as follows: Data and methods are described in section 2. Section 3 presents the observational results. Section 4 describes SST-forced model (IRI forecast models and CMIP5 AMIP experiment models) simulations and comparison with the observations. Results from CMIP5 historical experiments are presented in section 5, and conclusions and a discussion are presented in section 6 .

\section{Data and methods}

For precipitation, we use the following datasets: version 5 of Global Precipitation Climatology Centre (GPCC) monthly precipitation (Rudolf et al. 2010), which is a gauge-based, gridded global land surface dataset for the period from 1901 to the present day; time series (TS) version 3.1 of monthly precipitation over global land areas from Climatic Research Unit at the 

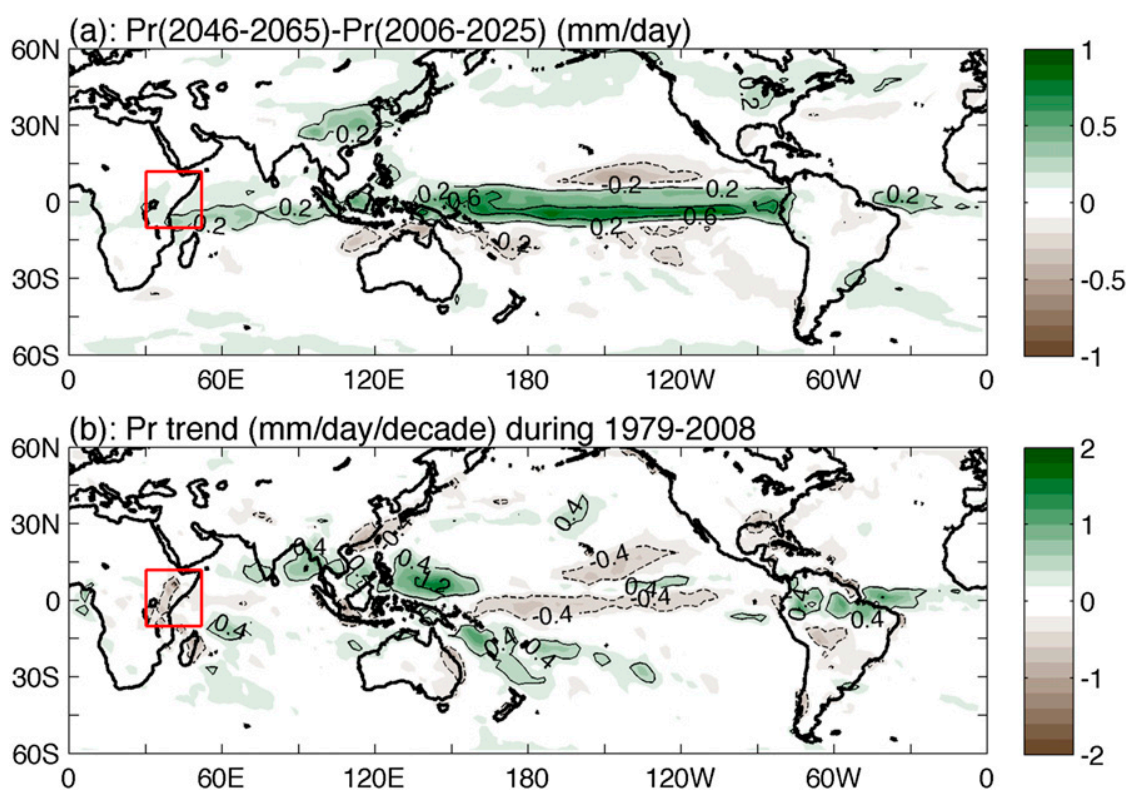

FIG. 1. (a) MAM precipitation rate difference between 2046-65 and 2006-25 from CMIP5 RCP4.5 projection multimodel mean. (b) MAM precipitation rate linear trend over the period of 1979-2008 from GPCP dataset. Red boxes in the two panels denote the East Africa area $10^{\circ} \mathrm{S}-12^{\circ} \mathrm{N}, 30^{\circ}-52^{\circ} \mathrm{E}$.

University of East Anglia (simply CRU hereafter; Mitchell and Jones 2005); version 2.2 of the Global Precipitation Climatology Project (GPCP) monthly precipitation dataset from 1979 to the present day (Huffman et al. 2009), which combines gauge observations and satellite data into $2.5^{\circ} \times 2.5^{\circ}$ global grids; and the Climate Prediction Center (CPC) Merged Analysis of Precipitation (CMAP) dataset (Xie and Arkin 1997), which is also monthly satellite and gauge data covering from 1979 to the present.

The observational SST is from the version $3 b$ of the National Oceanic and Atmospheric Administration (NOAA) National Climate Data Center (NCDC) Extended Reconstructed Sea Surface Temperature (ERSST; Smith et al. 2008), which is a globally gridded monthly dataset with a spatial resolution of $2^{\circ} \times 2^{\circ}$ that covers the period from 1854 to the present.

Historical simulations (from 1950 to the present) from three different IRI forecast models forced only with observed SST (http://iridl.ldeo.columbia.edu/SOURCES/. IRI/.FD/) include ECHAM4.5 (Roeckner et al. 1996), ECHAM5 (Roeckner et al. 2006), and the Community Climate Model, version 3.6 (CCM3.6; Kiehl et al. 1996). Each model has 24 ensemble members initialized with different atmospheric conditions. Both the ensemble mean and its range (represented as the 5th and 95th percentiles) are estimated for the climatology and historical time series but only the ensemble mean is used to examine the relationship between East African precipitation and SSTs.

The SST-forced models used in this paper also include 12 models from the CMIP5 AMIP experiment (see Table 1, including model name expansions). Each model has at least one ensemble member and some have as many as 10 (e.g., CSIRO Mk3.6.0). For each model, we only analyze the period between 1979 and 2008, which is the longest period shared by the 12 models. We also use the fully coupled models from the CMIP5 historical experiment (see Table 2, including model name expansions), of which there are 43 in total and the period of 1850-2005, common for almost all of the models, is used in the multimodel mean estimation. Note that the analysis of observations and the SST-forced models uses observed SSTs while the coupled models generate their own natural variability of SSTs and climate, which is not expected to be synchronous with natural variability in nature.

In this paper, the region of East Africa is represented by the land area $10^{\circ} \mathrm{S}-12^{\circ} \mathrm{N}, 30^{\circ}-52^{\circ} \mathrm{E}$ and (red box in Fig. 1). To reveal the SST anomaly pattern associated with the decadal variability the East African long rains, three types of analysis have been applied: empirical orthogonal function (EOF) analysis (Wilks 2011), linear regression analysis (regression of SST at each grid point on the time series of the East African long rains anomalies), and composite analysis (composite of SST 

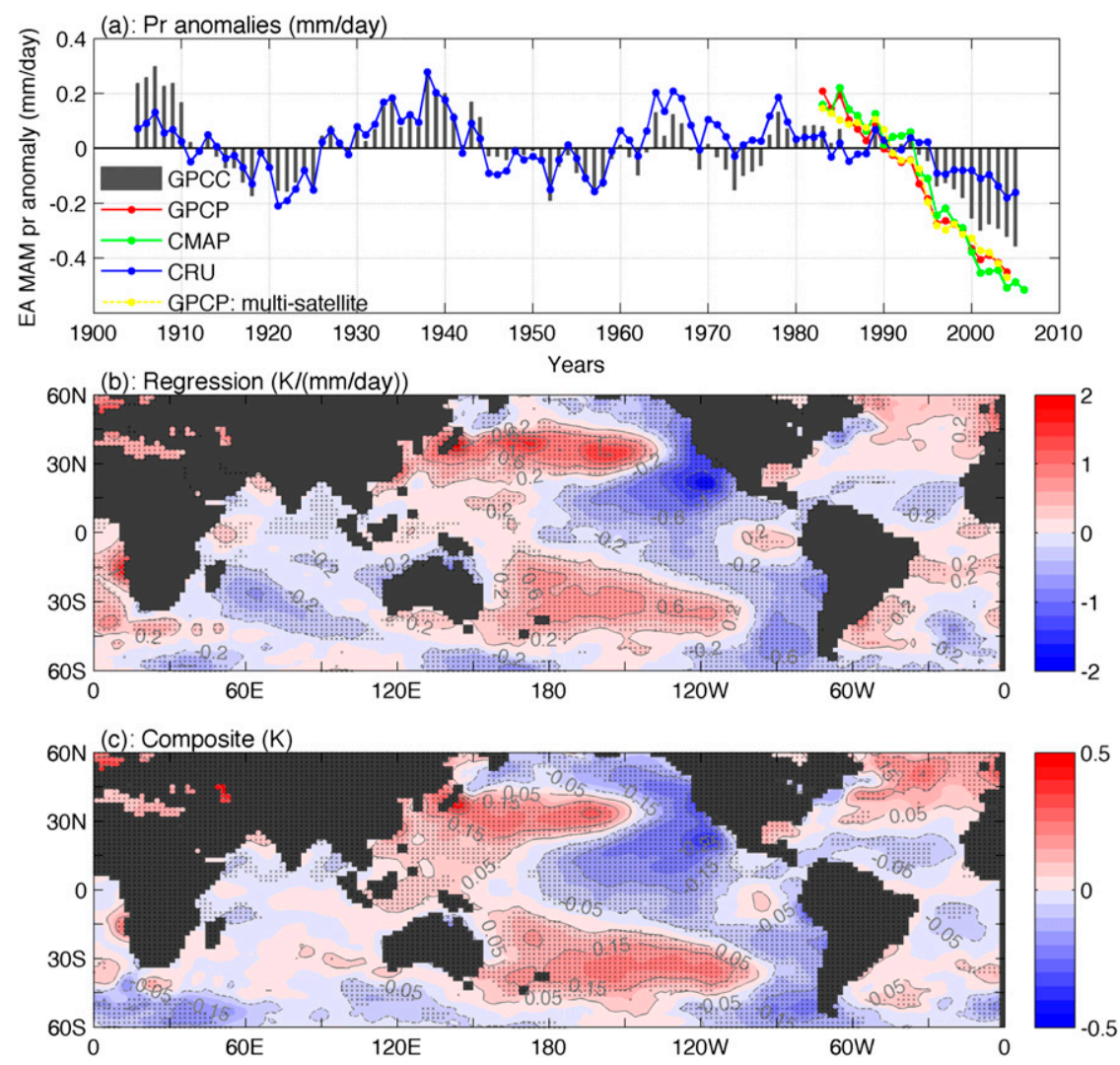

FIG. 2. (a) East Africa $\left(10^{\circ} \mathrm{S}-12^{\circ} \mathrm{N}, 30^{\circ}-52^{\circ} \mathrm{E}\right) \mathrm{MAM}$ precipitation rate anomaly relative to the 1979-2000 base in observations. A 9-yr running average has been applied to all the time series (although the 1979-2000 base is chosen and estimated based on the non-runningaveraged time series). (b) Regression of SST anomaly sst $t_{a}$ on the negative of East Africa precipitation rate anomaly $\operatorname{pr}_{a}$ (i.e., $b$ as in sst $_{a}=-b \times \mathrm{pr}_{a}$ ) in MAM over the period of 19012009. (c) Composite of MAM SST anomaly from years when East Africa MAM precipitation anomaly is below its one standard deviation. In both (b) and (c), the global average SST has been removed from the SST data by linear regression and a 9-yr running average has been applied to both the SST and the precipitation. The SST and precipitation data are from ERSST and GPCC respectively. Cross markers indicate being statistically significant at the 0.05 level.

anomalies over years when the East African long rains anomalies are below one standard deviation). In all the analyses, a 9-yr running average is applied to both the precipitation and SST datasets before performing the analysis.

\section{Observational analysis}

Figure 2a shows the 9-yr-running-averaged anomalies (relative to the 1979-2000 base) of the East African long rains in four observational datasets: GPCC, GPCP, CMAP, and CRU. The four datasets are consistent in showing drying over the most recent decades when all have data. The GPCC anomalies have a slightly smaller magnitude than the two satellite-gauge datasets GPCP and CMAP and the magnitude of the CRU drying is only about half that of GPCC. The estimated linear trends from 1983 onward are $-0.19,-0.33,-0.35$, and $-0.08 \mathrm{~mm} \mathrm{day}^{-1}$ decade $^{-1}$ in GPCC, GPCP, CMAP, and CRU, respectively. All of these trends are statistically significant at the 0.05 level. Estimation of the precipitation anomalies based on the multisatellite product (pure satellite product) from GPCP shows little difference from the satellite-gauge result, indicating that the recent drying trend is not driven by the loss of gauge coverage. The longer GPCC and CRU datasets suggest that the drying trend in the most recent decades is part of the decadal variability of climate over East Africa. There are at least four wet-dry cycles in the GPCC precipitation data for East Africa. The first one started around the beginning of the data period and ended around 1930. The second one extended from about 1930 
TABLE 1. Models from the CMIP5 AMIP experiment used in our analysis.

\begin{tabular}{|c|c|c|c|}
\hline Index & Model (expansion) & Time span & Ensemble No. \\
\hline 1 & $\begin{array}{l}\text { CanAM4 (Fourth-generation AGCM of the Canadian } \\
\text { Centre for Climate Modelling and Analysis) }\end{array}$ & 1950-2009 & 4 \\
\hline 2 & $\begin{array}{l}\text { CNRM-CM5 (Centre National de Recherches Météorologiques } \\
\text { Coupled Global Climate Model, version 5) }\end{array}$ & 1979-2008 & 1 \\
\hline 3 & $\begin{array}{l}\text { CSIRO Mk3.6.0 (Commonwealth Scientific and Industrial } \\
\text { Research Organisation Mark, version 3.6.0) }\end{array}$ & 1979-2009 & 10 \\
\hline 4 & $\begin{array}{l}\text { GFDL HIRAM-C180 [Geophysical Fluid Dynamics } \\
\text { Laboratory (GFDL) High Resolution Atmospheric } \\
\text { Model, 180-gridpoint resolution] }\end{array}$ & 1979-2008 & 3 \\
\hline 5 & $\begin{array}{l}\text { GFDL HIRAM-C360 (GFDL High Resolution } \\
\text { Atmospheric Model, 360-gridpoint resolution) }\end{array}$ & 1979-2008 & 2 \\
\hline 6 & $\begin{array}{l}\text { GISS-E2-R [Goddard Institute for Space Studies } \\
\text { (GISS) Model E2, coupled with the Russell ocean model] }\end{array}$ & 1880-2010 & 1 \\
\hline 7 & $\begin{array}{l}\text { HadGEM2-A (Hadley Centre Global Environment } \\
\text { Model, version 2-Atmosphere) }\end{array}$ & 1979-2008 & 1 \\
\hline 8 & $\begin{array}{l}\text { INM-CM4 (Institute of Numerical Mathematics } \\
\text { Coupled Model, version 4) }\end{array}$ & 1979-2008 & 1 \\
\hline 9 & $\begin{array}{l}\text { IPSL-CM5A-LR [L'Institut Pierre-Simon Laplace } \\
\text { (IPSL) Coupled Model, version 5A, low resolution] }\end{array}$ & 1979-2009 & 5 \\
\hline 10 & $\begin{array}{l}\text { MPI-ESM-LR [Max Planck Institute (MPI) Earth } \\
\text { System Model, low resolution] }\end{array}$ & 1979-2008 & 3 \\
\hline 11 & $\begin{array}{l}\text { MRI-AGCM3.2H [Meteorological Research Institute } \\
\text { AGCM, version } 3.2 \text { (high resolution)] }\end{array}$ & 1979-2008 & 1 \\
\hline 12 & $\begin{array}{l}\text { NorESM1-M [Norwegian Earth System Model, } \\
\text { version } 1 \text { (intermediate resolution)] }\end{array}$ & 1979-2008 & 3 \\
\hline
\end{tabular}

to the beginning of $1960 \mathrm{~s}$. The third one is relatively short, from the end of the second cycle to the mid-1970s. The last one started from the end of the third cycle to the present day and probably continues. The CRU data are generally consistent with the GPCC over the whole period and show similar decadal variability as in GPCC.

Besides the decadal variability described above, there is also a small centennial-scale drying trend of $-0.019 \mathrm{~mm} \mathrm{day}^{-1} \mathrm{decade}^{-1}$ (or $-0.19 \mathrm{~mm}$ day $^{-1}$ century $^{-1}$ ) in GPCC, similar to the time series over the same period in Fig. 1b from Tierney et al. (2013). It is unclear whether this trend is part of natural variability on longer time scales as in Tierney et al. (2013) or an indication of a global warming signal as in Williams and Funk (2011) or even associated with data issues (e.g., quality of data, the number of rain gauges used per grid point, and the way data have been interpolated) since the trend is much weaker in the CRU dataset (only $-0.041 \mathrm{~mm} \mathrm{day}^{-1}$ century $^{-1}$ ). However, if we assume the trend is due to global warming, as represented by either global mean SST or $\mathrm{CO}_{2}$ concentration, and there is a linear relationship between the warming and the corresponding response in East Africa MAM precipitation, then we can estimate the relative importance of natural and forced variability in East Africa MAM precipitation on decadal to centennial time scales. Figure 3a shows the 9-yr running average East Africa
MAM precipitation in GPCC before and after removing the postulated global warming component, as represented by global mean SST anomalies from ERSST. Removing the presumed global warming component decreases the magnitudes of wet anomalies at the beginning of the period and the dry anomalies over the last decade but does not change much the precipitation time series. The whole time series and the drying trend in recent decades are still dominated by natural variabilities. Using $\mathrm{CO}_{2}$ instead of global mean SST to represent the global warming forcing shows similar results (Fig. 3c). Since there is little drying trend on the centennial scale in the CRU dataset, the global warming component revealed by the linear regression method is much weaker than that of GPCC and the dominance of natural variability is even stronger (Figs. 3b,d).

Lyon et al. (2014) associated the recent East African long rains drought with maps of global MAM precipitation and SST anomalies and attributed the recent increase in drought frequency to multidecadal variability of SSTs in the tropical Pacific, with cooling in the east and warming in the west. Can similar SST anomaly patterns be found in historical intervals when East African long rains are also in dry phases? Figure 4 shows the maps of MAM precipitation anomalies over land and SST anomalies in the four periods when East African long rains are dry. Even though each dry period 
TABLE 2. Models of the CMIP5 historical experiment used in our analysis.

\begin{tabular}{|c|c|c|c|}
\hline Index & Model (expansion) & Time span & Ensemble No. \\
\hline 1 & $\begin{array}{l}\text { ACCESS1.0 [Australian Community Climate and Earth-System } \\
\text { Simulator (ACCESS), version 1.0] }\end{array}$ & 1850-2005 & 1 \\
\hline 2 & ACCESS1.3 (ACCESS, version 1.3) & 1850-2005 & 1 \\
\hline 3 & $\begin{array}{l}\text { BCC_CSM1.1 [Beijing Climate Center (BCC), Climate } \\
\text { System Model (CSM), version 1.1] }\end{array}$ & 1850-2012 & 3 \\
\hline 4 & BCC_CSM1.1-m (BCC_CSM1.1, moderate resolution) & 1850-2012 & 3 \\
\hline 5 & BNU-ESM (Beijing Normal University-Earth System Model) & 1850-2005 & 1 \\
\hline 6 & $\begin{array}{l}\text { CanCM4 (Fourth Generation Canadian Coupled } \\
\text { Global Climate Model) }\end{array}$ & 1961-2005 & 10 \\
\hline 7 & CanESM2 (Second Generation Canadian Earth System Model) & 1850-2005 & 5 \\
\hline 8 & CCSM4 (Community Climate System Model, version 4) & 1850-2005 & 6 \\
\hline 9 & $\begin{array}{l}\text { CESM1-BGC [Community Earth System Model, version } \\
1 \text { (CESM1), biogeochemical] }\end{array}$ & $1850-2005$ & 1 \\
\hline 10 & $\begin{array}{l}\text { CESM1-CAM5 (CESM1 with Community Atmosphere } \\
\text { Model, version 5) }\end{array}$ & $1850-2005$ & 3 \\
\hline 11 & $\begin{array}{l}\text { CESM1-CAM5.1-FV2 [CESM1 with CAM5.1 using } 2^{\circ} \text { finite } \\
\text { volume (FV) dynamical core] }\end{array}$ & $1850-2005$ & 4 \\
\hline 12 & CESM1-FASTCHEM (CESM1 with FASTCHEM) & 1850-2005 & 3 \\
\hline 13 & $\begin{array}{l}\text { CESM1-WACCM (CESM1 with Whole Atmosphere Community } \\
\text { Climate Model) }\end{array}$ & $1955-2005$ & 4 \\
\hline 14 & $\begin{array}{l}\text { CMCC-CESM [Centro Euro-Mediterraneo sui Cambiamenti } \\
\text { Climatici (CMCC) Community Earth System Model] }\end{array}$ & $1850-2005$ & 1 \\
\hline 15 & CMCC-CM (CMCC Climate Model) & $1850-2005$ & 1 \\
\hline 16 & CMCC-CMS (CMCC-CM with a resolved stratosphere) & 1850-2005 & 1 \\
\hline 17 & CNRM-CM5 (see Table 1) & $1850-2005$ & 10 \\
\hline 18 & CSIRO Mk3.6.0 (see Table 1) & 1850-2005 & 10 \\
\hline 19 & $\begin{array}{l}\text { FGOALS-g2 [Flexible Global Ocean-Atmosphere-Land } \\
\text { System Model (FGOALS) gridpoint, version 2] }\end{array}$ & 1900-2005 & 5 \\
\hline 20 & FGOALS-s2 (FGOALS, second spectral version) & 1850-2005 & 3 \\
\hline 21 & $\begin{array}{l}\text { FIO-ESM [First Institute of Oceanography (FIO) } \\
\text { Earth System Model] }\end{array}$ & $1850-2005$ & 3 \\
\hline 22 & GFDL CM3 (GFDL Climate Model, version 3) & 1860-2005 & 5 \\
\hline 23 & $\begin{array}{l}\text { GFDL-ESM2G (GFDL Earth System Model with } \\
\text { Generalized Ocean Layer Dynamics component) }\end{array}$ & $1861-2005$ & 3 \\
\hline 24 & $\begin{array}{l}\text { GFDL-ESM2M (GFDL Earth System Model with Modular } \\
\text { Ocean Model version } 4 \text { component) }\end{array}$ & $1861-2005$ & 1 \\
\hline 25 & $\begin{array}{l}\text { GISS-E2-H [GISS Model E2, coupled with the Hybrid } \\
\text { Coordinate Ocean Model (HYCOM) ocean model] }\end{array}$ & 1850-2005 & 5 \\
\hline 26 & GISS-E2-R (see Table 1) & 1850-2005 & 6 \\
\hline 27 & HadCM3 (Hadley Centre Coupled Model, version 3) & $1860-2005$ & 10 \\
\hline 28 & $\begin{array}{l}\text { HadGEM2-CC [Hadley Centre Global Environment } \\
\text { Model, version } 2 \text { (HadGEM2)-Carbon Cycle] }\end{array}$ & 1960-2004 & 3 \\
\hline 29 & HadGEM2-ES (HadGEM2-Earth System) & 1860-2004 & 4 \\
\hline 30 & INM-CM4 (see Table 1) & $1850-2005$ & 1 \\
\hline 31 & IPSL-CM5A-LR (see Table 1) & 1850-2005 & 5 \\
\hline 32 & $\begin{array}{l}\text { IPSL-CM5A-MR (IPSL Coupled Model, version } \\
\text { 5A, mid resolution) }\end{array}$ & $1850-2005$ & 1 \\
\hline 33 & $\begin{array}{l}\text { IPSL-CM5B-LR (IPSL Coupled Model, version } \\
\text { 5B, low resolution) }\end{array}$ & $1850-2005$ & 1 \\
\hline 34 & $\begin{array}{l}\text { MIROC-ESM [Model for Interdisciplinary Research on } \\
\text { Climate (MIROC), Earth System Model] }\end{array}$ & 1850-2005 & 3 \\
\hline 35 & $\begin{array}{l}\text { MIROC-ESM-CHEM (MIROC, Earth System } \\
\text { Model, Chemistry Coupled] }\end{array}$ & $1850-2005$ & 1 \\
\hline 36 & MIROC4h [MIROC, version 4 (high resolution)] & 1950-2005 & 3 \\
\hline 37 & MIROC5 (MIROC, version 5) & 1850-2005 & 4 \\
\hline 38 & MPI-ESM-LR (see Table 1) & 1850-2005 & 3 \\
\hline 39 & $\begin{array}{l}\text { MPI-ESM-MR (MPI Earth System Model, } \\
\text { medium resolution) }\end{array}$ & 1850-2005 & 3 \\
\hline
\end{tabular}


TABLE 2. (Continued)

\begin{tabular}{cllc}
\hline \hline Index & \multicolumn{1}{c}{ Model (expansion) } & Time span & Ensemble No. \\
\hline 40 & MPI-ESM-P (MPI Earth System Model, paleoclimate) & $1850-2005$ & 2 \\
41 & MRI-CGCM3 (Meteorological Research Institute Coupled & $1850-2005$ & \\
& Atmosphere-Ocean General Circulation Model, version 3) & $1850-2005$ & 3 \\
42 & NorESM1-M (see Table 1) & $1850-2005$ & \\
43 & NorESM1-ME [Norwegian Earth System Model, version 1 & & \\
& (intermediate resolution), with carbon cycle] & \\
\hline
\end{tabular}

has its own features, it seems the SST anomaly patterns over the Pacific Ocean are generally consistent over the four periods. Warm SST anomalies appear in the northern, northwestern, and southern Pacific while cool SST anomalies appear over the central to eastern Pacific. A small inconsistency is found over the central tropical Pacific during the period of 1945-63 (Fig. 4b) where warm SST anomalies appear. However, the SST anomalies over the eastern Pacific are still negative. Over other oceans, however, SST anomaly patterns are in general inconsistent. For example, the tropical Indian Ocean has warm SST anomalies during the periods of 1914-25 (Fig. 4a) and 1994-2005 (Fig. 4d) but cool anomalies during the periods of 1945-63 (Fig. 4b) and
1968-76 (Fig. 4c). Over the Atlantic Ocean, the periods of 1914-25 (Fig. 4a) and 1968-76 (Fig. 4c) have a pattern of cooling in the north but warming in the south while opposite patterns are found during the other two periods. Figure 5 shows the composite from the sign functions of the four SST anomaly maps in Fig. 4. Large positive or negative values appear over vast areas of the Pacific Ocean but not the Indian Ocean or the Atlantic Ocean, consistent with the previous analysis. Therefore, decadal variations in the East African long rains appear to be controlled by SST over the Pacific, consistent with the numerical experiment results in Lyon and DeWitt (2012) and Lyon et al. (2014), even though some studies suggest that the Pacific, Indian, and Atlantic Oceans all
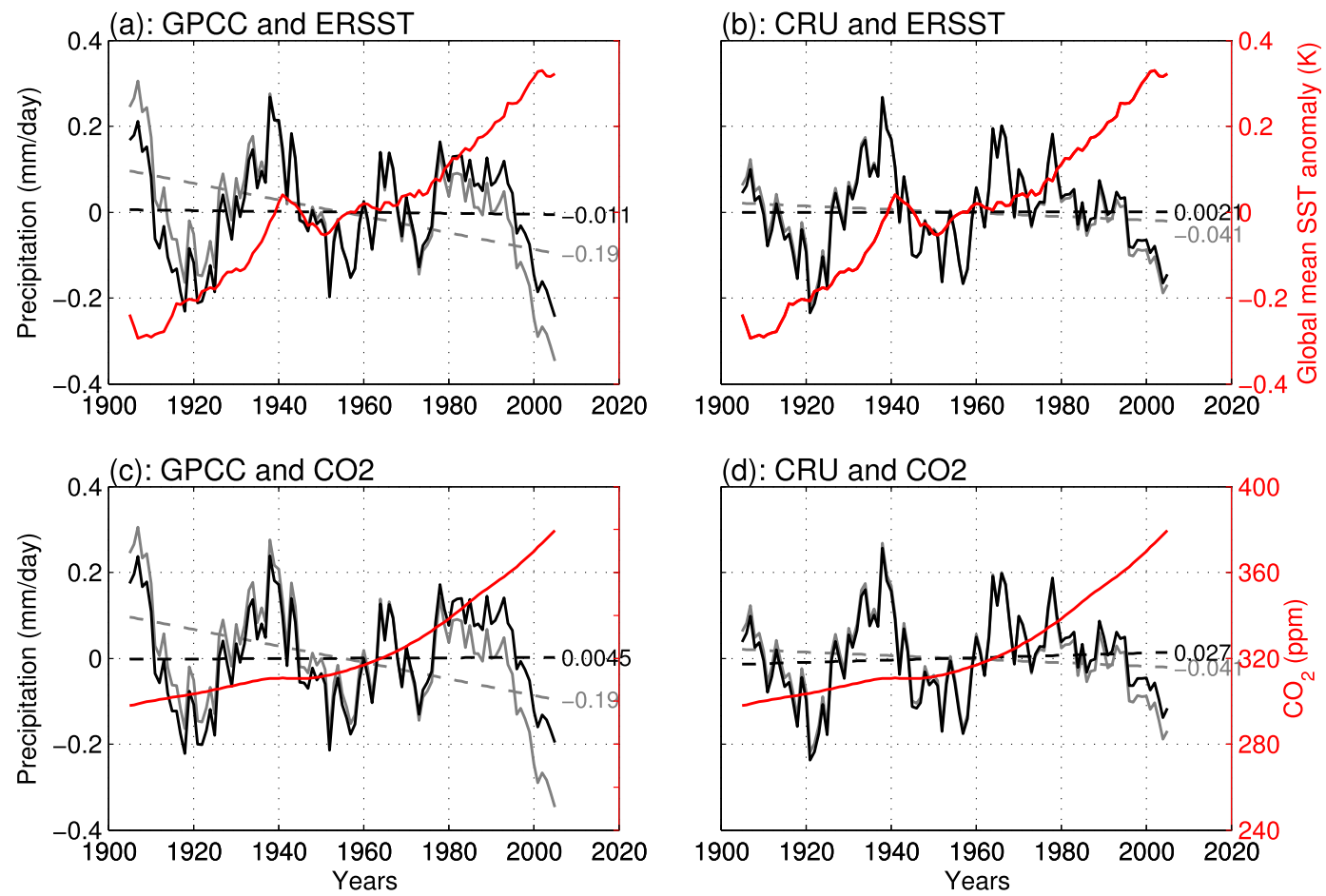

FIG. 3. East Africa MAM precipitation anomalies (gray lines) and their residuals (black lines) after removing the global warming signals (red lines). Dashed lines are the corresponding linear trends $\left(\mathrm{mm} \mathrm{day}^{-1}\right.$ century $^{-1}$ ). The precipitation datasets used are the (a),(c) GPCC and (b),(d) CRU, and global mean of MAM ERSST is used as the global warming signal in (a),(b) and the annual mean CO2 concentration is used in (c),(d). All time series have been low-pass filtered by applying a 9-yr running average. 
(a): 1914-1925
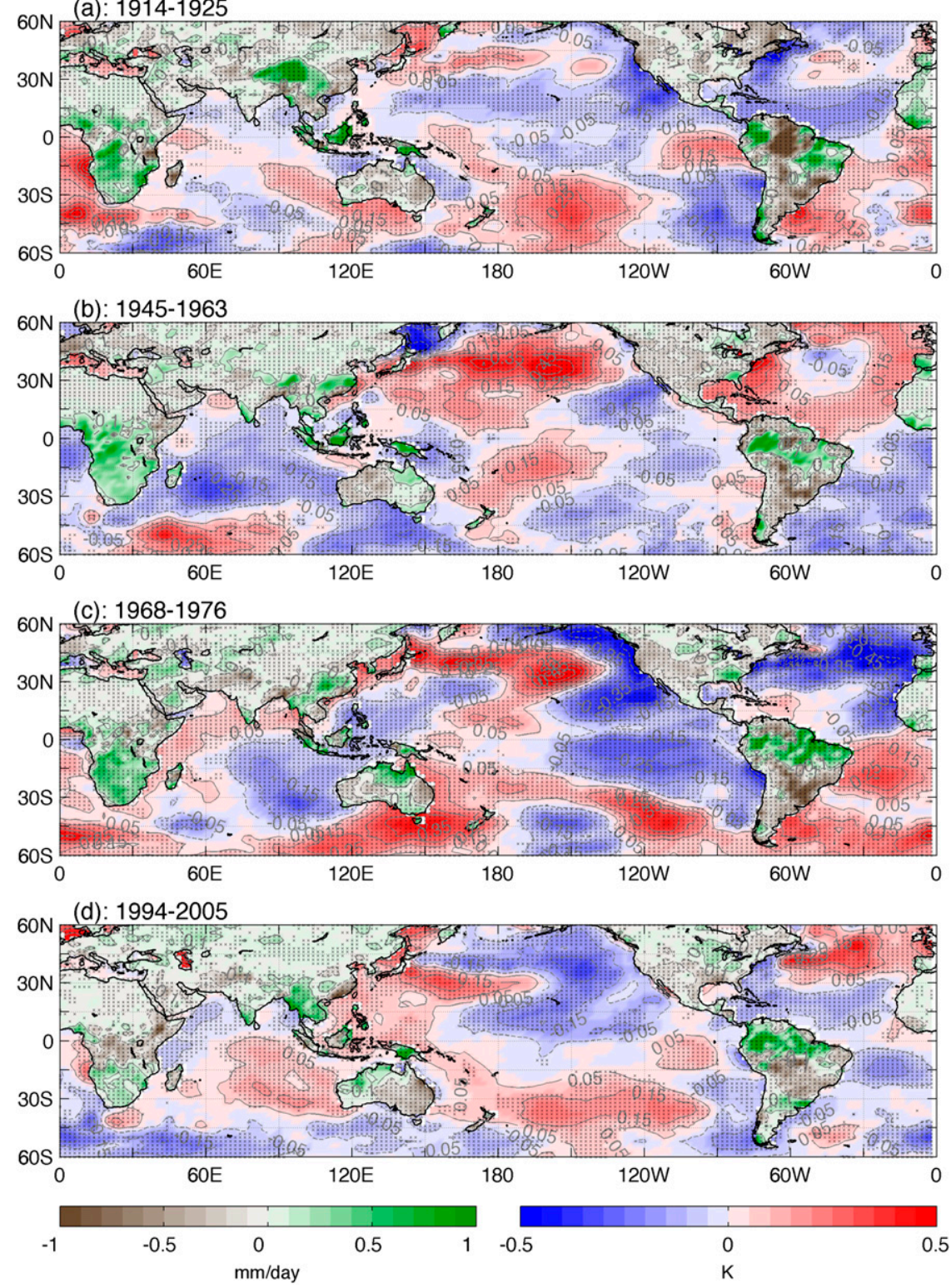

FIG. 4. Composite of MAM GPCC precipitation rate anomalies over land (brown-green colors) and MAM ERSST anomalies (blue-red colors). The global mean has been removed from the SST by linear regression and a 9-yr running average has been applied to both the SST and precipitation datasets before performing the composite analysis. Cross markers indicate being statistically significant at the 0.05 level.

contribute to the decadal variability of the East African long rains (Omondi et al. 2013). The SST patterns over the Pacific are similar to those found in studies of Pacific interdecadal climate variability such as that of Deser et al. (2004), although they focused on the boreal winter season. Along with the SST anomaly patterns over the Pacific, there are also consistent precipitation anomaly patterns around the global land areas [as noted by Herweijer and Seager (2008)], including wet anomalies in the southern Africa, dry anomalies in the western North America, and the wet-dry-wet pattern from north to south in South America. These consistent precipitation anomalies indicate that they might also be attributed to the same SST anomaly pattern in the Pacific as in the East African long rains case.

To obtain a more general relationship between the East African long rains and the global SST pattern, Fig. $2 b$ shows the map of regression of SST anomaly on 


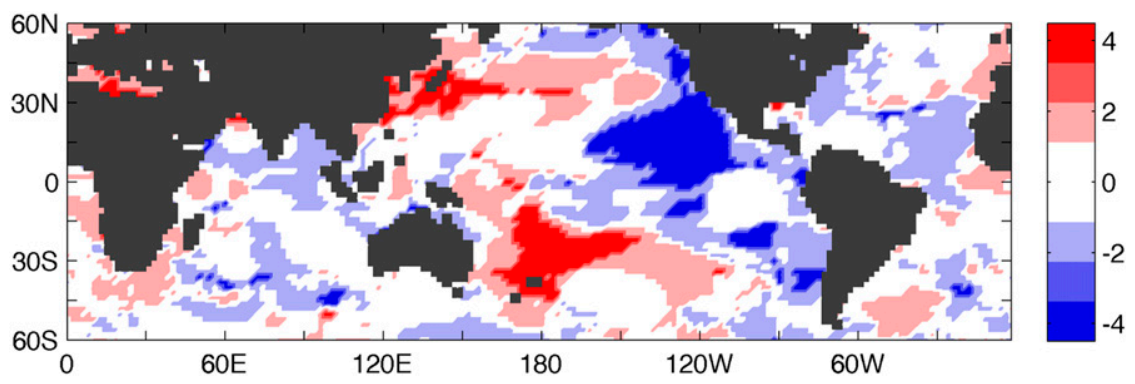

FIG. 5. Composite from the sign functions of the four SST anomaly maps in Fig. 4; that is, we set the values on each grid to be 1,0 , or -1 depending on whether the SST anomaly on the grid is greater than, equal to, or less than zero and add the four sign maps up. Large positive or negative values indicate strong consistence across the four maps of SST anomalies in Fig. 4.

the negative of the East African precipitation anomaly during the long rains. The global average has been removed from the SST by regression and a 9-yr running average applied to both the SST and the precipitation data. The regression coefficients show a La Niña-like spatial pattern, with negative values over the central and eastern tropical Pacific and positive values over the western tropical Pacific. Positive values are also found in the northern Pacific (around $40^{\circ} \mathrm{N}$ ) and southern Pacific (around $30^{\circ} \mathrm{S}$ ). These features are consistent with the composite results from different dry periods in Fig. 4. Choosing the years when the East African long rains anomalies are below one standard deviation during the whole period and making a composite map of the SST anomalies for these years again shows a similar pattern, confirming the robustness of the SST pattern (Fig. 2c). The SST anomaly composite in Fig. 2c also shows large values over the northern Atlantic but it does not mean it is associated with the East African long rains, as discussed in the previous paragraph.

Can we find a mode directly from the SST data that has a similar spatial pattern to that shown above and at the same time correlates with the East African long rains? Figure 6 shows the first EOF of the MAM SST after removing the global-averaged value so as to focus on natural variability. A 9-yr running average has also been applied to emphasize the decadal variability. The first EOF explains $22 \%$ of the total variance and shows a La Niña-like spatial pattern, with negative values over the central and eastern tropical Pacific and positive values over the western tropical Pacific. Positive values also appear over the northern Pacific (centered around $40^{\circ} \mathrm{N}$ ) and the southern Pacific (centered around $30^{\circ} \mathrm{S}$ ). This pattern is very similar to that derived by regressing or compositing based on the precipitation data. The first principal component ( $\mathrm{PC1}$, time series from the $\mathrm{EOF}$ analysis) shows decadal variability with positive and negative anomalies lasting from years to decades. PC1 is closely correlated with the East African long rains anomaly (correlation coefficient of -0.62). During the recent drying phase and that in the 1970s, PC1 had positive values. In contrast, during the wet phases in the 1980s, 1930s, and 1900s, PC1 had negative values. Therefore, the decadal variability of the East African long rains has a clear association with decadal SST variation over the Pacific, which is consistent with Lyon et al. (2014) but based on an analysis going further back in time.

\section{SST-forced models}

We began by showing the East African precipitation climatology for the SST-forced ECHAM4.5 simulations and the GPCC observations in Fig. 7. Unlike typical monsoon regions such as the Asian monsoon region where there is only one rainy season within a year and the rainy season appears in the summer months (Yang et al. 2013), there are primarily two rainy seasons across much of East Africa: the long rains (MAM) and the short rains (OND). In some areas there is a relative maximum in July and August since our East Africa region covers some area to the northwest where typical monsoon features emerge. The model simulations in general overestimate the precipitation climatology in every month but the overestimation is least in our months of interest, that is, March, April, and May (the long rains). The belt specified by the 5 th and 95 th percentiles of the 24 ensemble members is generally narrow, indicating that the simulated climatology does not differ much across the ensemble members. This gives us some confidence with regard to the capability of the model to simulate East African precipitation.

Figure 8a then shows the East African long rains anomaly in the ECHAM4.5 model simulations. Comparing with the GPCC data, the ensemble mean time series captures the drying trend since 1990 . The ensemble mean also captures the wetting trend from the mid-1950s to the late 1960s, but does not simulate the dry anomalies in the 1950s. An even larger discrepancy appears in the 

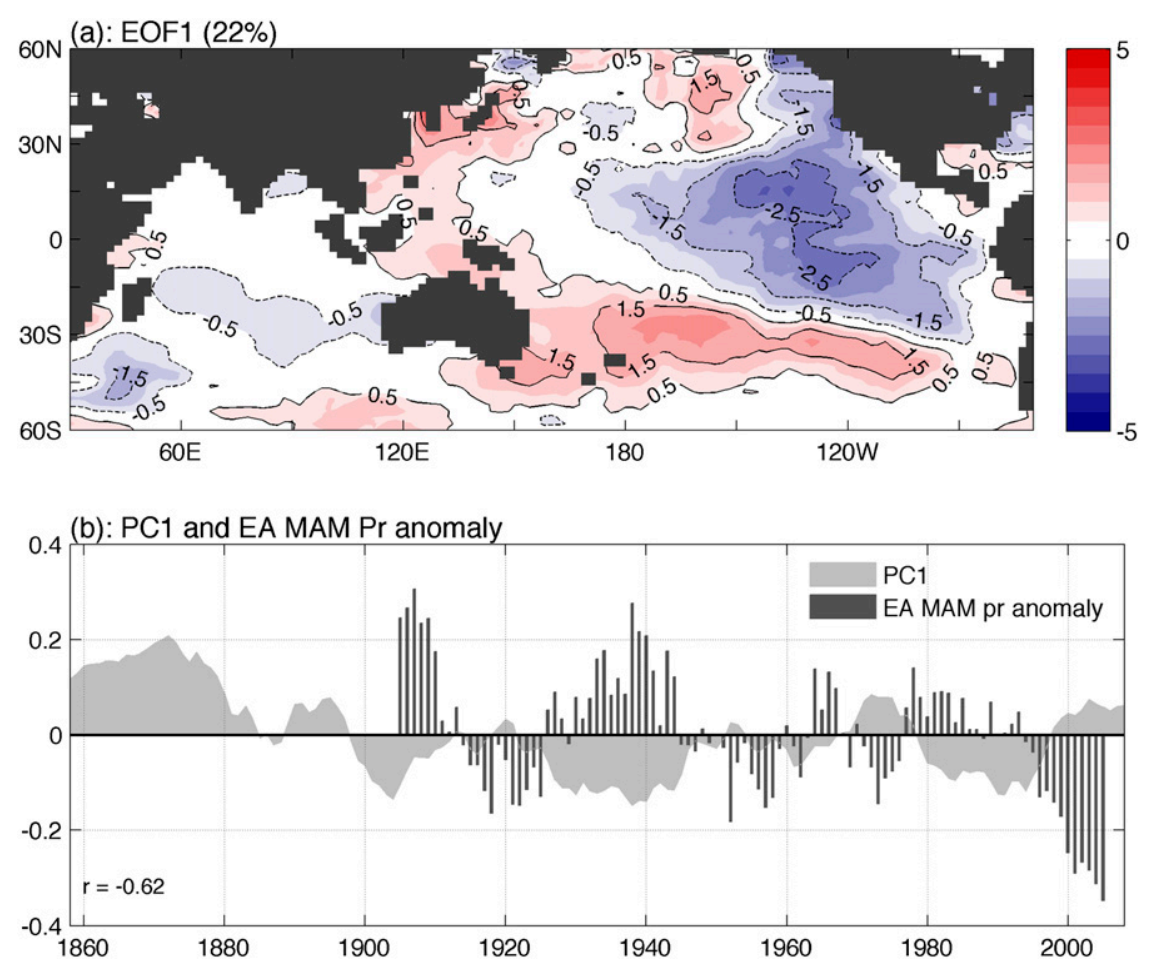

FIG. 6. The first EOF of the ERSST in MAM over domains of $60^{\circ} \mathrm{S}-60^{\circ} \mathrm{N}, 30^{\circ} \mathrm{E}-70^{\circ} \mathrm{W}$ after removing the global mean SST and performing a 9-yr running average. (a) The first EOF spatial pattern, and (b) the PC1 ( time series from the EOF analysis, lighter gray area plot; K) and East Africa MAM precipitation anomaly from GPCC (gray bars; $\mathrm{mm} \mathrm{day}^{-1}$ ).

1970s and 1980s when there seems little relation between modeled and observed precipitation. The width of the belt between the 5th and 95th percentiles exceeds the standard deviation of the ensemble mean time series, indicating that the modeled East African long rains are strongly influenced by internal variability in addition to the SST forced component.

To determine the SST pattern associated with East African long rains variability, Fig. $8 \mathrm{~b}$ shows the regression of ERSST on the ECHAM4.5 ensemble mean East African long rains precipitation. Comparing with the observed pattern (Fig. 2b), we see that the modeled regression pattern captures major large-scale observed features over the Pacific, although the modeled regression values over the northern Atlantic are much larger than the observed. For example, positive SST values appear in the western tropical Pacific while negative values lie in the central and eastern tropical Pacific. Similarly, there are also positive bands in the southern Pacific centered around $30^{\circ} \mathrm{S}$ and in the northern Pacific centered around $40^{\circ} \mathrm{N}$. The composite SST anomaly map over the East African dry long rains years (Fig. 8c) also resembles the ECHAM4.5 model captures the main features of the East African long rains-SST relationship.
We also did this analysis for the two other IRI forecast models, ECHAM5 and CCM3.6 (not shown). ECHAM5 underestimates the long rains precipitation climatology but resembles ECHAM4.5 in many of the features described above. CCM3.6 has the worst performance among the three models as it not only overestimates the long rains precipitation climatology but also has a wetting trend after 1996, which is opposite to the observed trend.

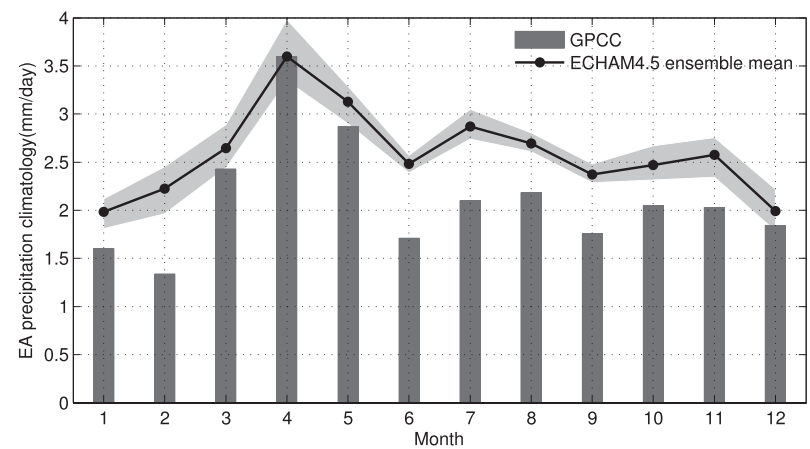

FIG. 7. East Africa $\left(10^{\circ} \mathrm{S}-12^{\circ} \mathrm{N}, 30^{\circ}-52^{\circ} \mathrm{E}\right)$ precipitation rate climatology in GPCC and ECHAM4.5 model simulations estimated over the period of 1979-2005. The gray area indicates the range between the 95 th and the 5 th percentiles of the 24 ensemble members. 

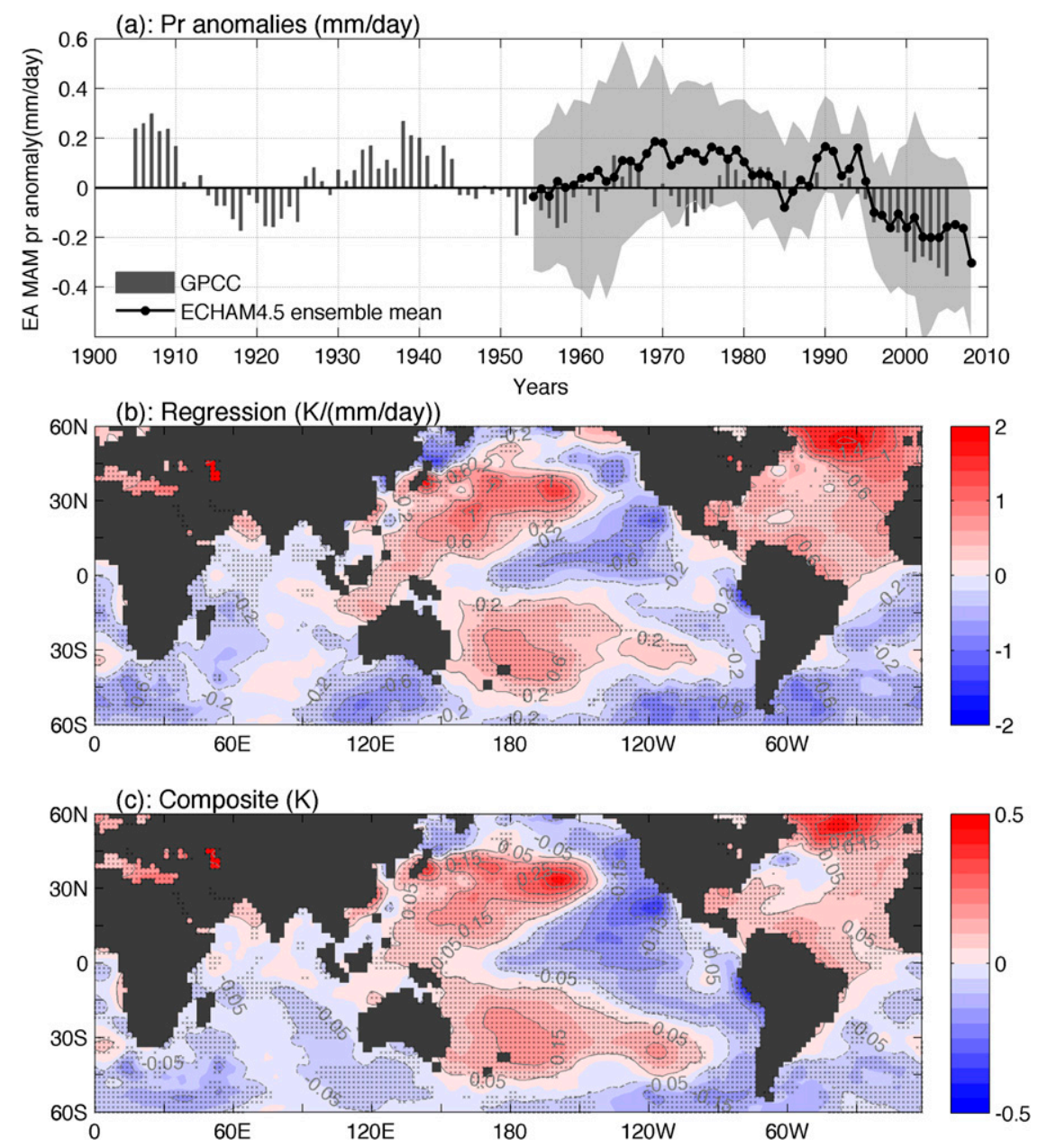

FIG. 8. As in Fig. 2, but for ECHAM4.5 instead of observations. The gray area in (a) indicates the range between the 95 th and the 5 th percentiles of the 24 ensemble members. The ensemble mean time series in (a) is used in (b), (c).

Figure 9 shows the East African precipitation climatology in the SST-forced CMIP5 AMIP experiments along with the observed values from GPCC. The multimodel ensemble mean agrees quite well with the GPCC climatology. The maximum model precipitation correctly appears in the long rain season (i.e., MAM). Compared with Fig. 7, the major difference is the broad spread among ensemble members. The width between the 5th and 95th percentiles in the CMIP5 AMIP ensemble is much larger than for the ECHAM4.5 ensemble, indicating greater internal variability introduced by differences among models.

As most models in the CMIP5 AMIP experiment only cover the period from 1979 to the present day, it is difficult to examine the decadal variability in these simulations. However, we can assess whether the simulations produce the behavior since 1979. Figure 10a shows the time history of the East African long rains anomaly in the CMIP5 AMIP experiment models. The ensemble mean shows an overall drying trend, especially after 1990. The magnitude of the drying trend, however, is smaller than for GPCC and occurs amidst a large spread among the ensemble members.

Both the regression of SST anomaly on the East African long rains anomaly (Fig. 10b) and the East African dry MAM years composite of SST anomalies (Fig. 10c) show La Niña-like patterns, similar to the results in the observations and the IRI forecast models. This indicates that the ensemble mean of the CMIP5 AMIP experiment simulations is capable of capturing the relationship between the East African long rains and the SST anomaly pattern, although capability is limited only to recent decades.

\section{CMIP5 historical experiment}

Figure 11 shows the East African precipitation climatology in the coupled CMIP5 historical experiments. The multimodel mean climatology does not agree with 


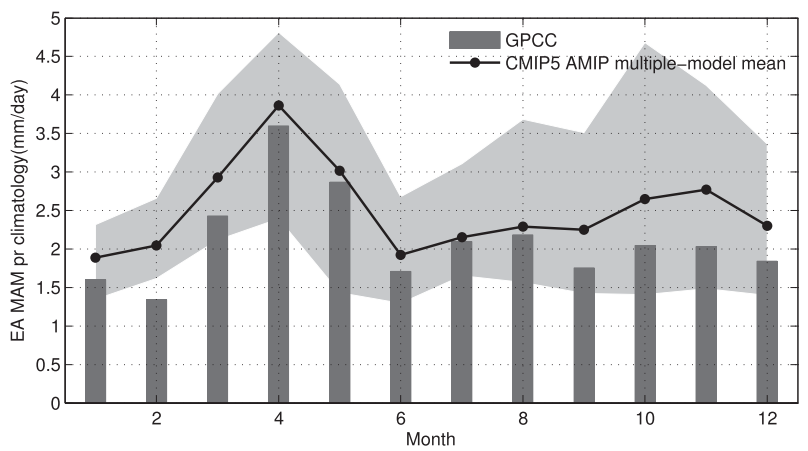

FIG. 9. As in Fig. 7, but for CMIP5 AMIP multimodel runs instead of ECHAM4.5.

the observations; it is clearly worse than the SST-forced IRI forecast models and CMIP5 AMIP simulations. It underestimates the long rains (MAM) and overestimates the short rains (OND). The long rains peak during May instead of April as in the observations. The spread is quite large. All of these problems have also been reported in CMIP3 models (Anyah and Qiu 2012). The drop in realism of the precipitation simulation relative to the SST-forced atmosphere models arises in errors introduced by the simulation of SSTs.

The multimodel mean among coupled models cancels out most of the internal variabilities, whether generated by internal atmospheric or coupled atmosphereocean variability, and isolates the externally forced change. The CMIP5 historical multimodel mean does not capture the time series of the East African long rains anomaly (Fig. 12a), showing only a weak wetting trend after 1950. This forced wetting trend is consistent with the twenty-first-century projections of the IPCC AR4 models (Fig. 7a in Held and Soden 2006) and the CMIP5 models (Fig. 1a). However, as the forced response is still weak relative to the natural variability, it is difficult to say whether East Africa will have drier or wetter long rains in the near future since this will strongly depend on the future evolution of natural variability.
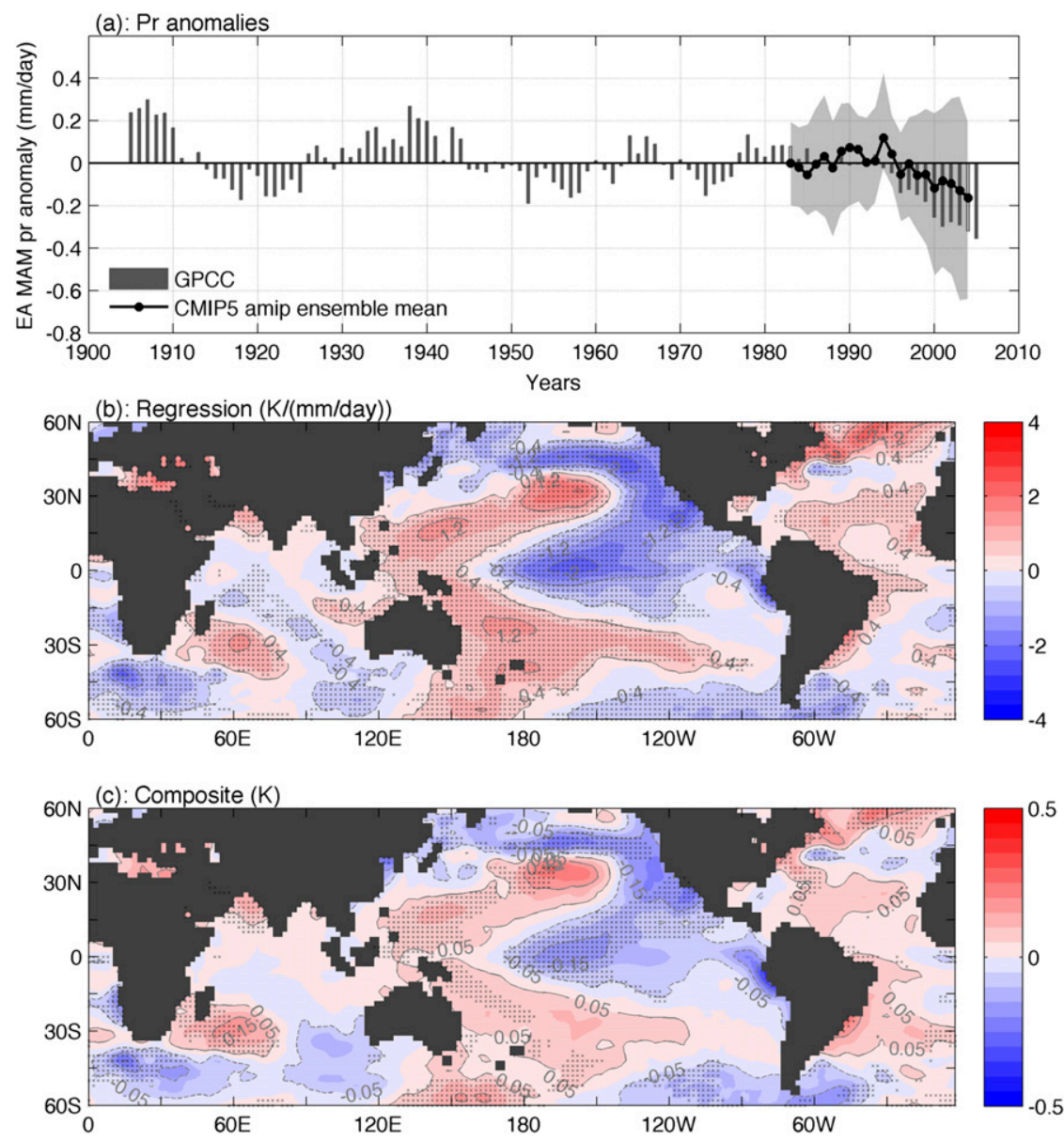

FIG. 10. As in Fig. 8, but for CMIP5 AMIP multimodel runs instead of ECHAM4.5. 


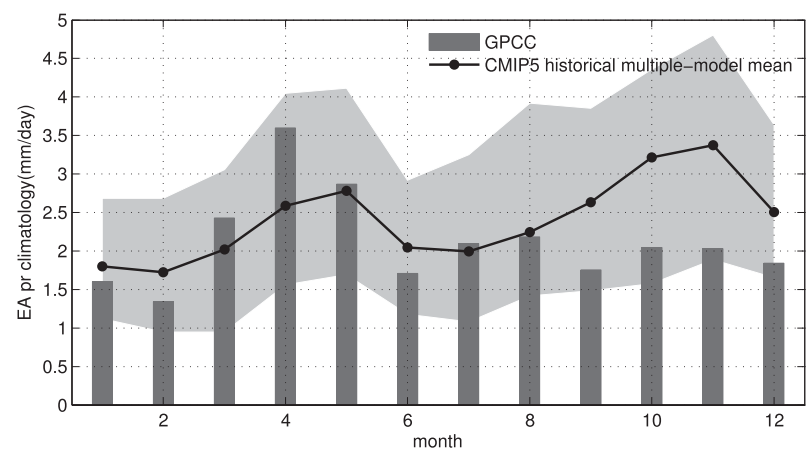

FIG. 11. As in Fig. 7, but for CMIP5 historical multimodel runs instead of ECHAM4.5.

Figure $12 \mathrm{~b}$ shows the multimodel composite SST anomaly pattern for dry East African MAM years of the CMIP5 historical simulations, where a 9-yr running mean is used again to identify the dry years. Comparing with Fig. 2c, there are many differences from the observations. However, the CMIP5 historical simulations capture the observed relation with the SST gradient over the tropical Pacific Ocean, although the cool anomalies over the central tropical Pacific and the gradient are much weaker than observed. The significance of the composite SST anomaly pattern is indicated in Fig. 12c, where the composite is performed for each model and the number of models with positive composite values at each grid point is counted. This pattern is in general consistent with Fig. 12b, with warm anomalies in the western tropical Pacific being the most robust model feature. The large negative values appearing over the Indian Ocean in Figs. $12 \mathrm{~b}$ and $12 \mathrm{c}$ suggest that the Indian Ocean also is important for the decadal variability of the East African long rains in the CMIP5 coupled models. Comparing to Fig. 2, we see that the CMIP5 coupled models overestimate the Indian Ocean's relation to the East African long rains climate on these time scales.
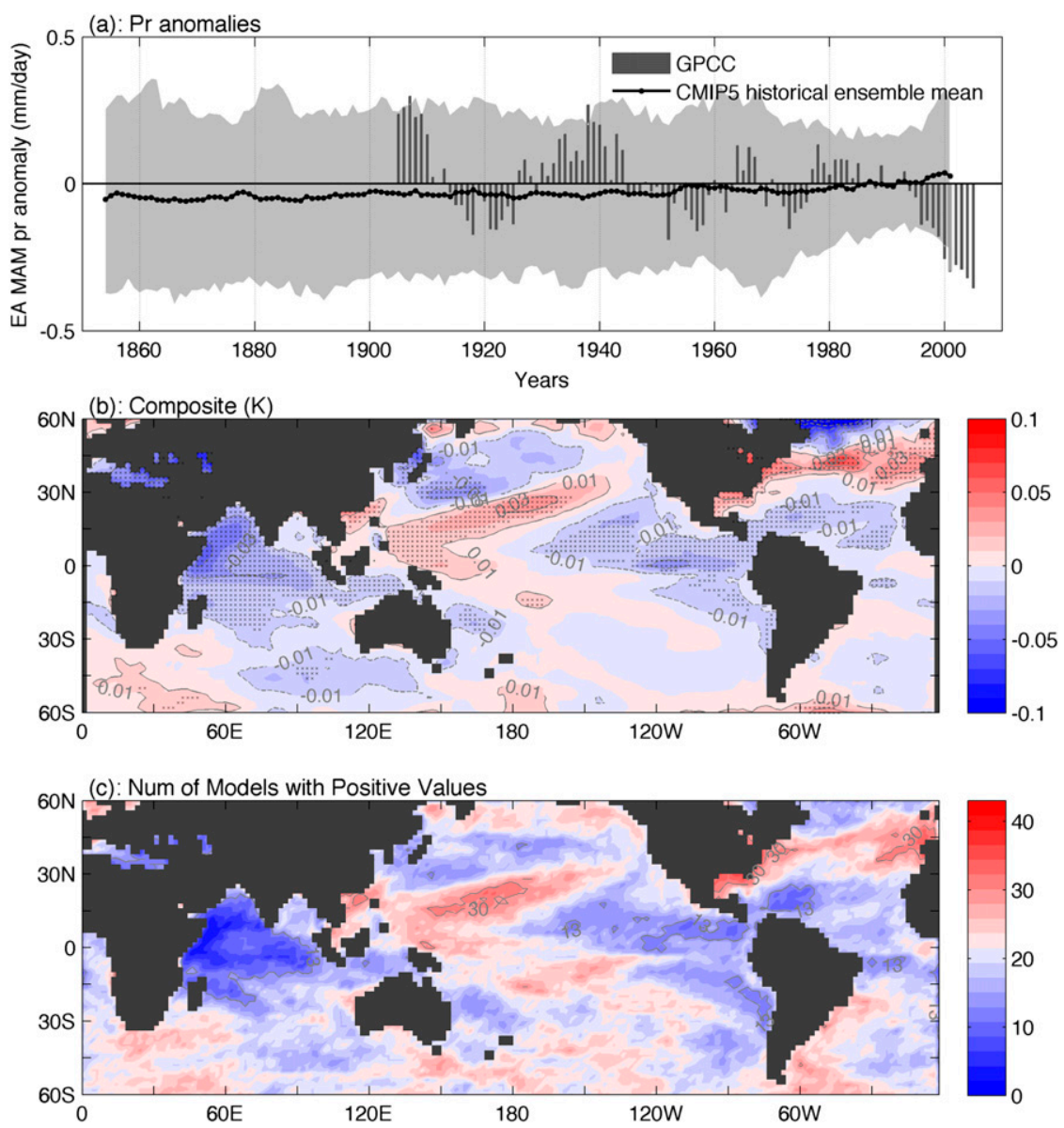

FIG. 12. (a),(b) As in Figs. 8a and 8c, respectively, but for CMIP5 historical multimodel runs instead of ECHAM4.5. (c) Number of models with positive values in the composite analysis. 


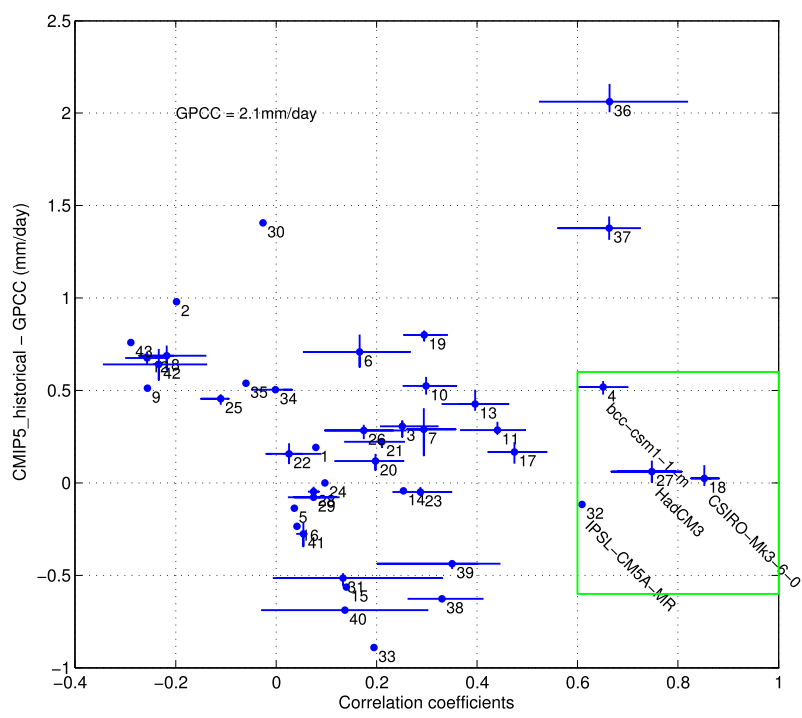

FIG. 13. Scatterplot of correlation coefficients against annual mean differences between the climatology of East Africa precipitation in CMIP5 historical experiment models and that in GPCC. Blue dots denote the ensemble mean values of each model and the blue lines represent the range of ensemble members of each model. Numbers to the bottom right of the blue dots are the indices of the 43 CMIP5 historical experiment models (Table 2). Models within the green box are the four best models based on the two scores of correlation coefficients and the annual mean difference.

As the multimodel mean of the CMIP5 historical experiments is poor in capturing the East African long rains-SST relationship and even simulates an incorrect climatology, it is interesting to examine the performances of the individual models. Figure 13 shows the scatterplot of correlation coefficients against the differences of annual mean between the seasonal cycles of the East African precipitation in the CMIP5 historical simulations and that in GPCC. The mean values among the ensemble members for each individual model are denoted by dots and the corresponding ranges are denoted by lines. The larger the correlation coefficients and the smaller the absolute values of the differences, the better the models' performances. The criteria that the correlation coefficients are $>0.6$ and the absolute values of the differences are $<0.6 \mathrm{~mm} \mathrm{day}^{-1}$ (denoted by the green box) leaves four models that are best in simulating the East African precipitation seasonal cycle: CSIRO Mk3.6.0, HadCM3, IPSL-CM5A-MR, and BCC_CSM1.1-m. The four best coupled models indeed do a much better job in simulating the observed climatology (Fig. 14) than the multimodel mean (Fig. 11). Models CSIRO Mk3.6.0 and BCC_CSM1.1-m have almost the same long rains precipitation climatology as the observed although they both overestimate the short rains climatology, which is the same problem as in the case of the multimodel mean.
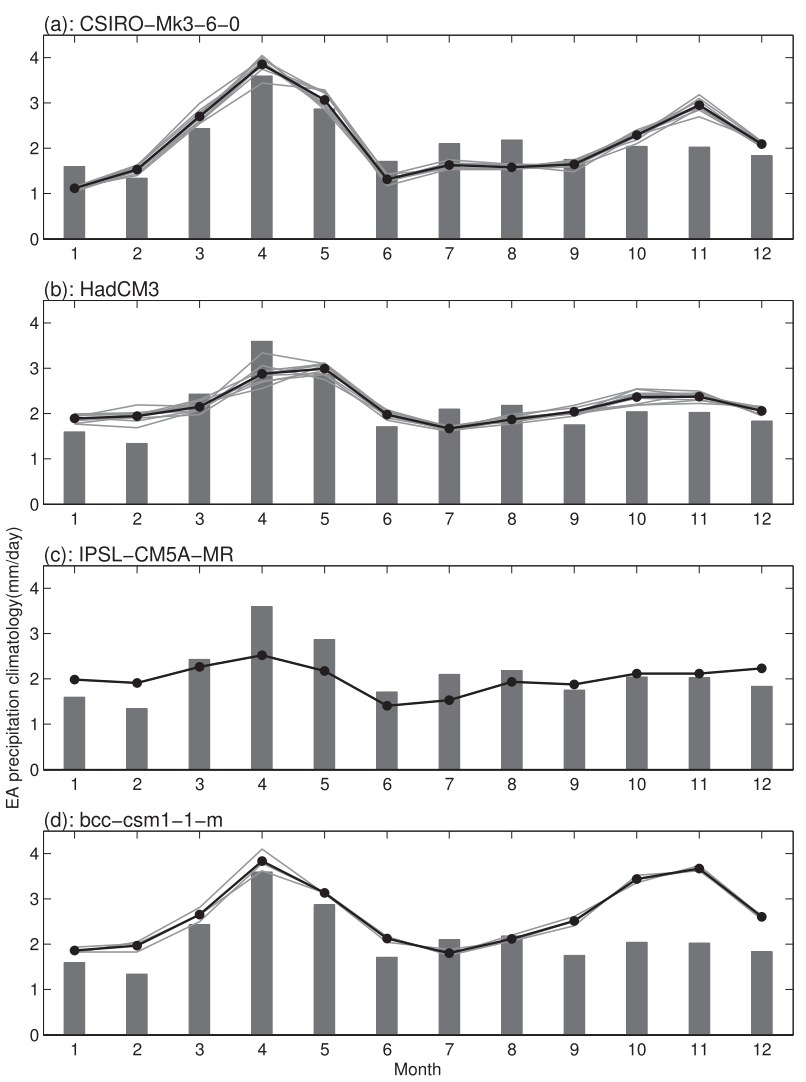

FIG. 14. As in Fig. 11, but for the four best models.

Models HadCM3 and IPSL-CM5A-MR capture the short rains climatology very well but both underestimate the long rains climatology.

Are the four models that are best at simulating the East African precipitation climatology able to capture the precipitation-SST relationship in the observations as shown in Fig. 2c? Figure 15 shows the ensemble mean of the composite SST anomalies when the East African long rains precipitation anomalies within each ensemble member are below one standard deviation and Fig. 16 shows the corresponding time series. Of the four coupled models, CSIRO Mk3.6.0, IPSL-CM5A-MR, and BCC_CSM1.1-m capture the cool anomalies over the central and eastern Pacific, although the magnitudes are in general smaller than observed. HadCM3 has a contrast of cool (warm) to the north (south) of the equator over the tropical Pacific, which is totally different from the observed pattern. The observed positive bands in the southern and northern Pacific can only be seen in the CSIRO Mk3.6.0 model. The CSIRO Mk3.6.0 model seems to be the only model that captures both the East African precipitation climatology and the East African long rains precipitation-SST relationship in the observations. The time series from the four models' 

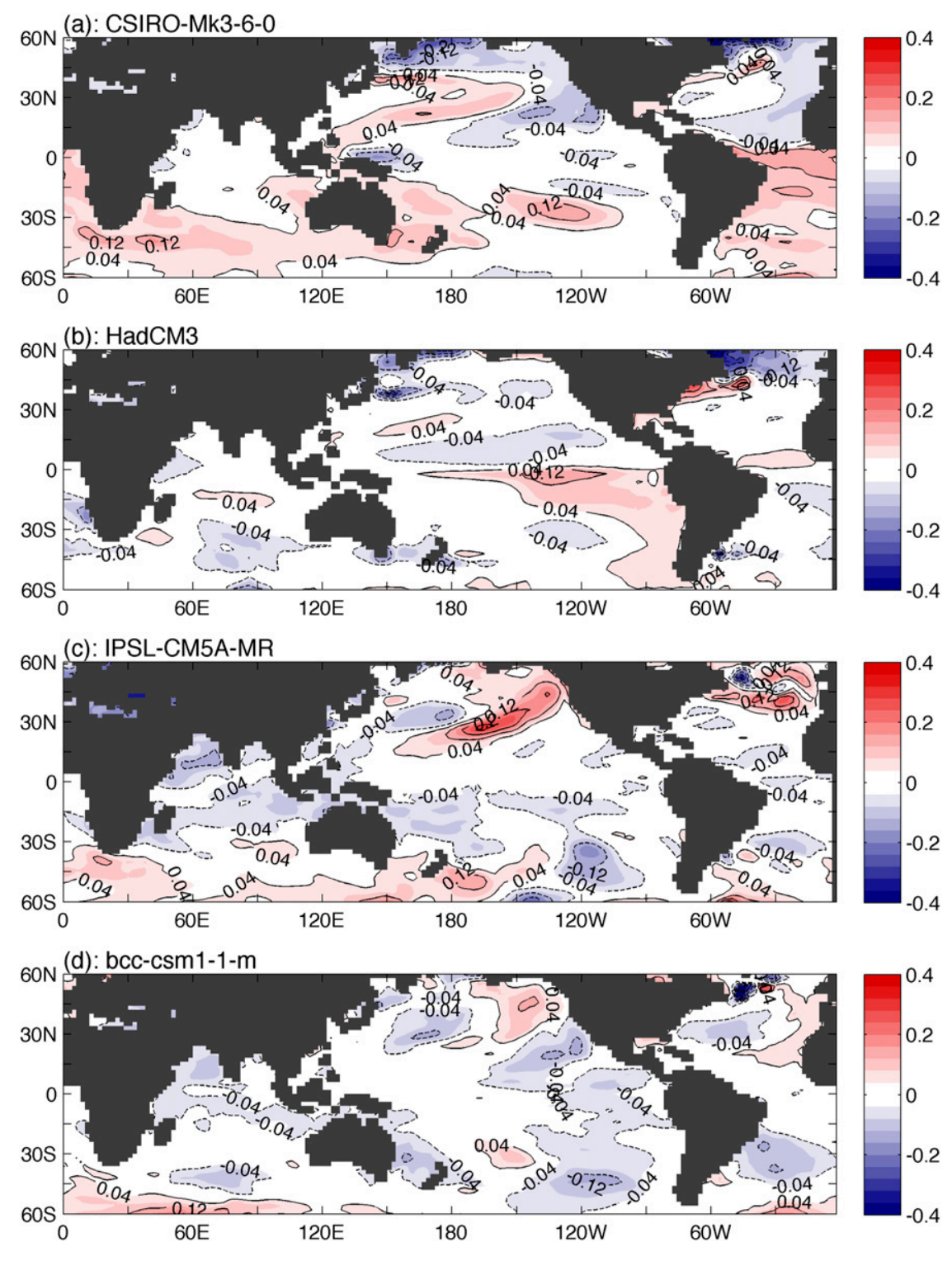

FIG. 15. As in Fig. 12b, but for the four best models.

simulations (Fig. 16) seem to have realistic amplitudes compared to the observed but they are not synchronous with it, which is expected because of internal variabilities. At least three of the four models (not CSIRO Mk3.6.0) have a wetting trend for the multirun mean since 1990, which is opposite to the observations, indicating limited skills of these coupled models in predicting the East African long rains decadal variability.

\section{Conclusions and discussion}

The 2010-11 East African severe drought raised the question of whether it is forced by anthropogenic emissions of greenhouse gases or just a phase of long-term natural variability (Lott et al. 2013). Previous studies (e.g., Held and Soden 2006) and our own estimate from CMIP5 (Fig. 1a) show that the East African long rains are projected to get wetter under global warming, which is opposite to the recent drying trend. By using different methods of analysis and focusing on decadal variability, our study reveals that the drying trend is most likely part of decadal variability associated with natural SST variability mainly in the Pacific Ocean and with a La Niñalike pattern as in Lyon and DeWitt (2012) and Lyon et al. (2014). The following conclusions have been reached:

- The drying trend of the East African long rains in recent decades most likely arises from natural decadal variability and is not of anthropogenic origin. 

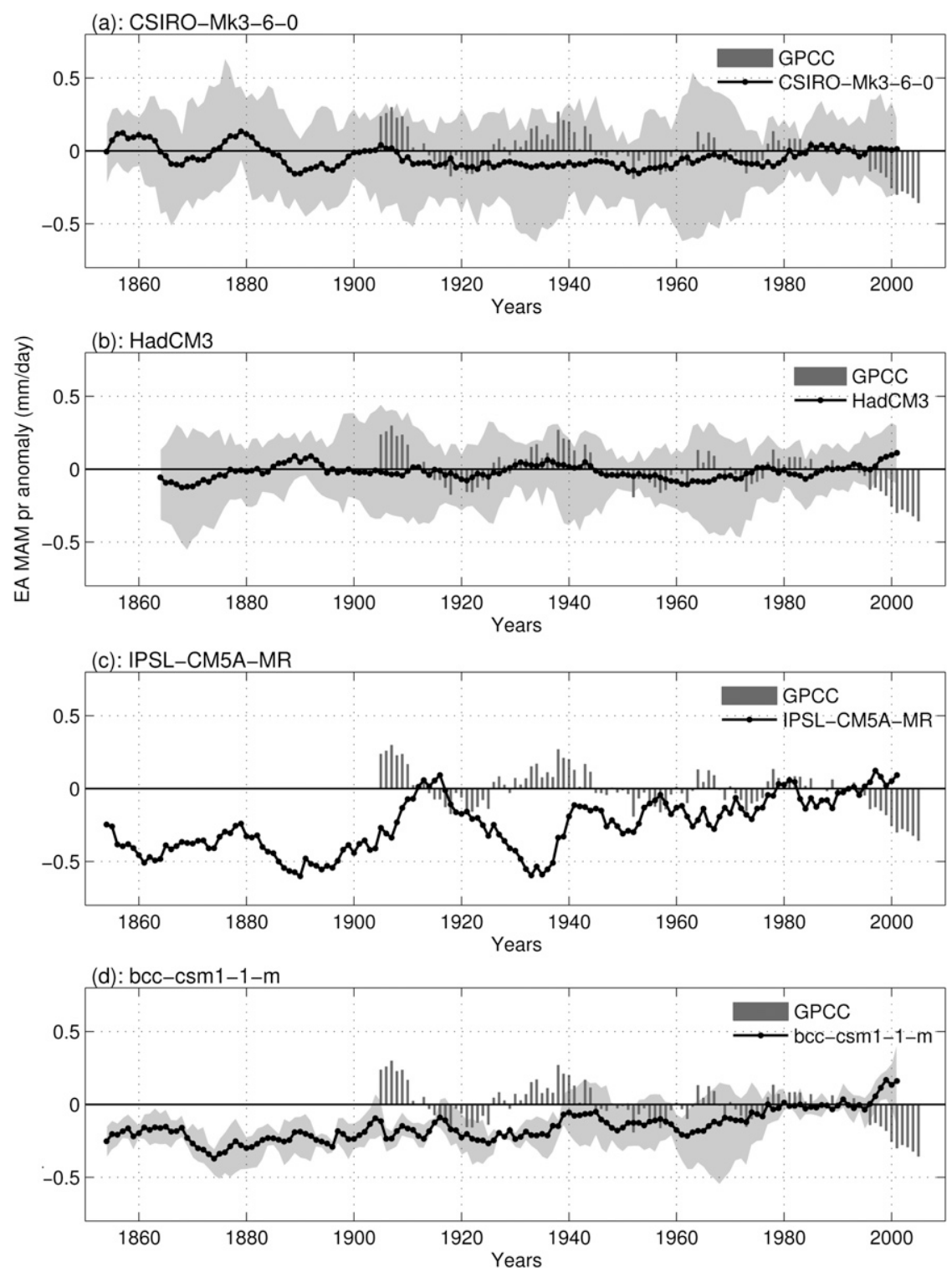

FIG. 16. As in Fig. 12a, but for the four best models.

- The decadal variability of the East African long rains can be explained by the decadal variability of SST over the Pacific Ocean. The dry phases of the East African long rains are associated with positive SST anomalies over the western tropical Pacific and negative anomalies over the central and eastern tropical Pacific (La Niña-like).

- ECHAM4.5 and ECHAM5 from the SST-forced IRI forecast models are able to capture the precipitation climatology, the SST anomaly pattern associated with decadal variability, and the drying trend in recent decades. However, not all the models perform well (e.g., CCM3.6 is not even able to capture the recent drying trend).
- The SST-forced models of the CMIP5 AMIP experiments also capture the climatology of the East Africa precipitation, although with varying skills. The simulated East African long rains anomaly, which is only available over a short period, does capture the recent observed drying trend in the multimodel mean and the associated SST anomaly pattern is consistent with the observed.

- The multimodel mean of the fully coupled models of the CMIP5 historical experiment underestimates the East African long rains and overestimates the short rains with a considerable range of performance among the individual models. The multimodel mean of the 
precipitation anomalies shows a weak wetting trend since 1950 that is much smaller than the internal variability. The SST anomaly pattern associated with the dry phase of the East African long rains is associated with a SST gradient over the tropical Pacific, although the magnitude of this is weak compared to observations.

- CSIRO Mk3.6.0 is the best model among the CMIP5 historical experiment coupled models that captures both the East African precipitation climatology and the East African long rains-SST relationship in the observations.

While SST-forced models are able to capture the recent drying trend in the East African long rains and much of the decadal variability since 1950s, fully coupled models have systematic errors in simulating the East African precipitation climatology (i.e., underestimating the long rains precipitation while overestimating the short rains precipitation) and give somewhat different SST patterns associated with decadal variability of the East African long rains. This lack of coupled model skill casts doubt on projections of future East African precipitation and on the use of these models to understand past variations (e.g., Tierney et al. 2013).

Strong internal decadal variability of the long rains precipitation in East Africa, and the generally poor ability of models to reproduce this and its atmosphereocean causes, means that our ability to predict future variations is very limited. It should not be assumed that recent drying trends represent an anthropogenically forced precipitation change and that the trends will continue. Nor should it be assumed that the model projection of wetting in response to rising greenhouse gases is correct. We are distressingly far from an adequate understanding or a usable ability to model climate variability and change in this socially critical region.

Acknowledgments. This work was supported by NOAA Award NA10OAR4310137 (Global Decadal Hydroclimate Variability and Change). Funding for BL was provided by the National Science Foundation under Award AGS 12-52301. We thank Jason Smerdon, Jess Tierney, and Yochanan Kushnir for useful discussions and three reviewers for their comments.

\section{REFERENCES}

Anchukaitis, K. J., and J. E. Tierney, 2013: Identifying coherent spatiotemporal modes in time-uncertain proxy paleoclimate records. Climate Dyn., 41, 1291-1306, doi:10.1007/s00382-012-1483-0.

Anyah, R. O., and W. Qiu, 2012: Characteristic 20th and 21st century precipitation and temperature patterns and changes over the Greater Horn of Africa. Int. J. Climatol., 32, 347-363, doi:10.1002/joc.2270.
Camberlin, P., and N. Philippon, 2002: The East African MarchMay rainy season: Associated atmospheric dynamics and predictability over the 1968-97 period. J. Climate, 15, 1002-1019, doi:10.1175/1520-0442(2002)015<1002:TEAMMR>2.0.CO;2.

Cane, M. A., A. C. Clement, A. Kaplan, Y. Kushnir, D. Pozdnyakov, R. Seager, S. E. Zebiak, and R. Murtugudde, 1997: Twentiethcentury sea surface temperature trends. Science, 275, 957-960, doi:10.1126/science.275.5302.957.

Chen, J., B. E. Carlson, and A. D. Del Genio, 2002: Evidence for strengthening of the tropical general circulation in the 1990s. Science, 295, 838-841, doi:10.1126/science.1065835.

Compo, G. P., and P. D. Sardeshmukh, 2010: Removing ENSOrelated variations from the climate record. J. Climate, 23, 1957-1978, doi:10.1175/2009JCLI2735.1.

Cook, K. H., and E. K. Vizy, 2013: Projected changes in East African rainy seasons. J. Climate, 26, 5931-5948, doi:10.1175/ JCLI-D-12-00455.1.

Deser, C., A. S. Phillips, and J. W. Hurrell, 2004: Pacific interdecadal climate variability: Linkages between the tropics and the North Pacific during boreal winter since 1900. J. Climate, 17, 3109-3124, doi:10.1175/1520-0442(2004)017<3109: PICVLB $>2.0 . C O ; 2$.

FEWS NET, cited 2011: East Africa: Past year one of the driest on record in the eastern Horn. Famine Early Warning System Network Report. [Available online at http://reliefweb.int/ report/ethiopia/east-africa-past-year-one-driest-record-easternhorn-june-14-2011.]

Held, I., and B. Soden, 2006: Robust responses of the hydrological cycle to global warming. J. Climate, 19, 5686-5699, doi:10.1175/JCLI3990.1.

Herweijer, C., and R. Seager, 2008: The global footprint of persistent extra-tropical drought in the instrumental era. Int. J. Climatol., 28, 1761-1774, doi:10.1002/joc.1590.

Hoerling, M., and Coauthors, 2011: On North American decadal climate for 2011-20. J. Climate, 24, 4519-4528, doi:10.1175/ 2011JCLI4137.1.

Huffman, G. J., R. F. Adler, D. T. Bolvin, and G. Gu, 2009: Improving the global precipitation record: GPCP version 2.1. Geophys. Res. Lett., 36, L17808, doi:10.1029/2009GL040000.

Kelley, C., M. Ting, R. Seager, and Y. Kushnir, 2012: Mediterranean precipitation climatology, seasonal cycle, and trend as simulated by CMIP5. Geophys. Res. Lett., 39, L21703, doi:10.1029/2012GL053416.

Kiehl, J. T., J. J. Hack, G. B. Bonan, and B. Boville, 1996: Description of the NCAR Community Climate Model (CCM3). NCAR Tech. Note NCAR/TN-420+STR, 152 pp, doi:10.5065/ D6FF3Q99.

L'Heureux, M. L., S. Lee, and B. Lyon, 2013: Recent multidecadal strengthening of the Walker circulation across the tropical Pacific. Nat. Climate Change, 3, 571-576, doi:10.1038/ nclimate1840.

Lott, F. C., N. Christidis, and P. A. Stott, 2013: Can the 2011 East African drought be attributed to human-induced climate change? Geophys. Res. Lett., 40, 1177-1181, doi:10.1002/ $\operatorname{grl} .50235$.

Lu, J., G. Vecchi, and T. Reichler, 2007: Expansion of the Hadley cell under global warming. Geophys. Res. Lett., 34, L06805, doi:10.1029/2006GL028443.

Lyon, B., and D. G. DeWitt, 2012: A recent and abrupt decline in the East African long rains. Geophys. Res. Lett., 39, L02702, doi:10.1029/2011GL050337.

, A. Barnston, and D. G. DeWitt, 2014: Tropical Pacific forcing of a 1998-99 climate shift: Observational analysis and climate 
model results for the boreal spring season. Climate Dyn., 43, 893-909, doi:10.1007/s00382-013-1891-9.

Mason, S. J., and L. Goddard, 2001: Probabilistic precipitation anomalies associated with ENSO. Bull. Amer. Meteor. Soc., 82, 619-638, doi:10.1175/1520-0477(2001)082<0619:PPAAWE >2.3.CO;2.

Mitchell, T. D., and P. D. Jones, 2005: An improved method of constructing a database of monthly climate observations and associated high-resolution grids. Int. J. Climatol., 25, 693-712, doi:10.1002/joc.1181.

Ogallo, L., 1988: Relationships between seasonal rainfall in East Africa and the southern oscillation. J. Climatol., 8, 31-43, doi:10.1002/joc.3370080104.

Omondi, P., L. A. Ogallo, R. Anyah, J. M. Muthama, and J. Ininda, 2013: Linkages between global sea surface temperatures and decadal rainfall variability over Eastern Africa region. Int. J. Climatol., 33, 2082-2104, doi:10.1002/joc.3578.

Roeckner, E., and Coauthors, 1996: The atmospheric general circulation model ECHAM-4: Model description and simulation of present-day climate. MPI Rep. 218, 94 pp. [Available online at https://www.mpimet.mpg.de/fileadmin/ publikationen/Reports/MPI-Report_218.pdf.]

- and Coauthors, 2006: Sensitivity of simulated climate to horizontal and vertical resolution in the ECHAM5 atmosphere model. J. Climate, 19, 3771-3791, doi:10.1175/ JCLI3824.1.

Rudolf, B., A. Becker, U. Schneider, A. Meyer-Christoffer, and M. Ziese, 2010: GPCC status report December 2010. 7 pp. [Available online at http://www.dwd.de/bvbw/generator/DWDWWW/Content/ Oeffentlichkeit/KU/KU4/KU42/en/Reports_Publications/GPCC status_report_2010,templateId=raw,property=publicationFile. pdf/GPCC_status_report_2010.pdf.]

Russell, J., and T. Johnson, 2007: Little Ice Age drought in equatorial Africa: Intertropical convergence zone migrations and El Niño-Southern Oscillation variability. Geology, 35, 21-24, doi:10.1130/G23125A.1.

Seager, R., and Coauthors, 2007: Model projections of an imminent transition to a more arid climate in southwestern North America. Science, 316, 1181-1184, doi:10.1126/ science.1139601.
_ N. Naik, and G. A. Vecchi, 2010: Thermodynamic and dynamic mechanisms for large-scale changes in the hydrological cycle in response to global warming. J. Climate, 23, 4651-4668, doi:10.1175/2010JCLI3655.1.

Smith, T. M., R. W. Reynolds, T. C. Peterson, and J. Lawrimore, 2008: Improvements to NOAA's historical merged landocean surface temperature analysis (1880-2006). J. Climate, 21, 2283-2296, doi:10.1175/2007JCLI2100.1.

Taylor, K. E., R. J. Stouffer, and G. A. Meehl, 2012: An overview of CMIP5 and the experiment design. Bull. Amer. Meteor. Soc., 93, 485-498, doi:10.1175/BAMS-D-11-00094.1.

Tierney, J. E., J. E. Smerdon, K. J. Anchukaitis, and R. Seager, 2013: Multidecadal variability in East African hydroclimate controlled by the Indian Ocean. Nature, 493, 389-392, doi:10.1038/nature11785.

Vecchi, G. A., and B. J. Soden, 2007: Global warming and the weakening of the tropical circulation. J. Climate, 20, 43164340, doi:10.1175/JCLI4258.1.

Verschuren, D., K. R. Laird, and B. F. Cumming, 2000: Rainfall and drought in equatorial east Africa during the past 1,100 years. Nature, 403, 410-414, doi:10.1038/35000179.

Vizy, E. K., and K. H. Cook, 2012: Mid-twenty-first-century changes in extreme events over northern and tropical Africa. J. Climate, 25, 5748-5767, doi:10.1175/JCLI-D-11-00693.1.

Wilks, D. S., 2011: Statistical Methods in the Atmospheric Sciences. 3rd ed. Academic Press, 676 pp.

Williams, A. P., and C. Funk, 2011: A westward extension of the warm pool leads to a westward extension of the Walker circulation, drying eastern Africa. Climate Dyn., 37, 2417-2435, doi:10.1007/s00382-010-0984-y.

Xie, P., and P. A. Arkin, 1997: Global precipitation: A 17-year monthly analysis based on gauge observations, satellite estimates, and numerical model outputs. Bull. Amer. Meteor. Soc., 78, 2539-2558, doi:10.1175/1520-0477(1997)078<2539: GPAYMA $>2.0 . \mathrm{CO} ; 2$.

Yang, W., R. Seager, and M. A. Cane, 2013: Zonal momentum balance in the tropical atmospheric circulation during the global monsoon mature months. J. Atmos. Sci., 70, 583-599, doi:10.1175/JAS-D-12-0140.1. 